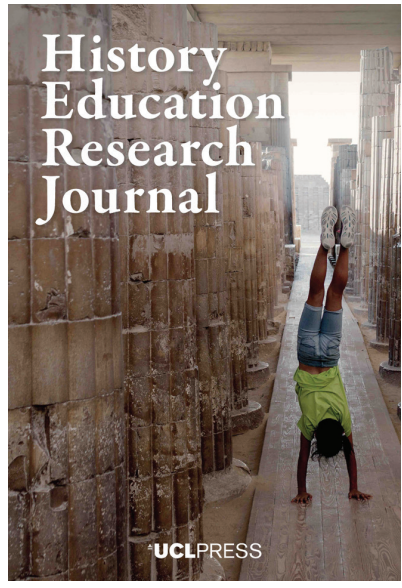

${ }^{\star}$ UCLPRESS

HISTORY EDUCATION RESEARCH JOURNAL

ISSN 2631-9713 (Online)

Journal homepage:

https://www.uclpress.co.uk/pages/history-educationresearch-journal

\title{
Cultivating historical consciousness in the history classroom: Uncovering the subtleties of student meaning making with the help of found poetry
}

Nathalie Popa iD

\section{How to cite this article}

Popa, N. (2021) 'Cultivating historical consciousness in the history classroom: Uncovering the subtleties of student meaning making with the help of found poetry'. History Education Research Journal, 18 (2), 224-46. https://doi.org/10.14324/HERJ.18.2.06

Submission date: 15 January 2021

Acceptance date: 28 June 2021

Publication date: 19 October 2021

\section{Peer review}

This article has been peer-reviewed through the journal's standard double-blind peer review, where both the reviewers and authors are anonymised during review.

\section{Copyright}

(C) 2021 Popa. This is an open-access article distributed under the terms of the Creative Commons Attribution Licence (CC BY) 4.0 https://creativecommons.org/licenses/by/4.0/, which permits unrestricted use, distribution and reproduction in any medium, provided the original author and source are credited.

\section{Open access}

The History Education Research Journal is a peer-reviewed open-access journal. 


\title{
Cultivating historical consciousness in the history classroom: Uncovering the subtleties of student meaning making with the help of found poetry
}

\author{
Nathalie Popa* - McGill University, Canada
}

\begin{abstract}
This article explores student meaning making in a Grade 11 US history unit on the Second World War. The 10-lesson unit was designed as an experiment that aimed to apply an instructional model of historical consciousness to a classroom context. Although the notion of historical consciousness has gained significant interest in the field of history education, translating it into educational practice remains a challenge. In this study, it refers to a disposition to make meaning of the past for oneself, which is manifested in three meaning-making abilities and processes (Boix Mansilla and Gardner, 2007; Nordgren and Johansson, 2015; Rüsen, 2004). To study the manifestation of historical consciousness in the learning process during this unit, I employed found poetry on collected classroom transcripts and observations, as well as student work. I turned to this qualitative, arts-informed method when I realised the analytic methods that I had employed so far failed to capture important subtleties of students' historical consciousness emerging from the data. In this paper, I present and discuss the results of my analysis, offer a rationale for using found poetry in history education research and reflect on the need for relevant and meaningful school history.
\end{abstract}

Keywords: history education, historical consciousness, learning processes, design research, found poems

\section{Introduction}

In this article, I explore how students made historical meaning during a designinspired, experimental unit on the history of the Second World War. Michael, the teacher participant in my study, taught the unit in his Grade 11 US history class in March 2018. In collaboration with him, I designed this 10-lesson unit with the intent of putting an innovative instructional model of historical consciousness to the test. Conducting thematic inquiry on classroom transcripts, participant observations and student documents, my analysis yielded rich descriptive insights about student learning in this specific case. However, in the process of analysing the material, I found that I was unable to capture aspects of meaning making that I considered salient or moving when I conducted classroom observations and close readings of student work. My interest in found poetry, an arts-informed research method, evolved out of this concern. Here, I offer a discussion of four poems that emerged from my found poetry analysis. These poems reveal deep and varied ways in which students engaged in historical meaning making. 
The work in this article builds on recent efforts to theorise and operationalise historical consciousness for educational purposes. I begin with a presentation of the scholarly backdrop to the inquiry. I then describe the theoretical perspectives that guided the study. Following this, I elaborate on methodological considerations. Next, I offer the results of my found poetry analysis in the form of four poems, each accompanied by a commentary that serves to describe and interpret the poems. After this, I discuss what these findings might tell us about historical consciousness in educational practice, and I mention implications of the study for research in the field of history education. Finally, I summarise the paper and suggest avenues for future inquiries. The purpose of this article is twofold: to share insights into the process of learning that took place in a design experiment where teaching utilised an innovative instructional model to promote historical consciousness, and to argue for the interest of arts-informed research methodologies, namely found poetry, for history education research.

\section{Background}

The issue of making history education more relevant for students has attracted a great deal of attention over the past decades. As recently articulated in the 2019 EuroClio (European Association of History Educators) Annual Conference entitled 'Bringing History to Life', researchers, educators and others in the field are concerned about 'How can we better engage students in history?', and 'How can we make history teaching meaningful for them?' (De Julio, 2019: n.p.). Indeed, research shows that many students fail to see the purpose or importance of learning history in school (Haydn and Harris, 2010; Lee and Howson, 2009; Van Straaten et al., 2015, 2018), or alternatively, they see its value and interest, but do not feel engaged in its study because of the content of their lessons and the way it is taught to them (Angvik and Von Borries, 1997; Grever et al., 2011; Traille, 2007; VanSledright, 2011; Virta, 2016). Thus, in an effort to make history more relevant, the field has engaged in rich international debates that try to focus learning away from the straightforward acquisition of facts and concepts towards the development of competences, which promote, for instance, the examination of historical material, the construction and deconstruction of interpretations, and reflection upon how the past shapes the present and the future (see Carretero et al., 2017; Köster et al., 2014; Stearns et al., 2000).

As part of this ongoing conversation, scholars have produced fruitful conceptual work, even though some concepts may overlap in their definitions and implications. The notion of historical consciousness, which has gained significant interest over the past years, is a prime example of this. It is generally used to refer to the process whereby humans grasp the connections between past, present and future in order to navigate their place in time (Ahonen, 2001; Clark and Grever, 2018; Clark and Peck, 2019; Karlsson, 2011; Körber, 2015; Lee, 2004; Rüsen, 2004, 2012; Seixas, 2012, 2017; Van Straaten et al., 2015; Von Borries, 2011; Zanazanian and Nordgren, 2019). However, even though it is widely believed that historical consciousness holds great potential for revitalising the relevance of history education, the concept has proven to be complicated to work with. Indeed, it has been described as 'hard to pin down' (Laville, 2004: 67), as 'vague and rather enigmatic' (Grever and Adriaansen, 2019: 815) and as 'a catch-all term which can be used quite differently' (Körber, 2015: 6). Unsurprisingly, one leading history educationalist argues that the research community faces the important 'challenge [of] moving from the theoretical to an educational program', and reminds us of the need to conceive 'a framework that would offer guidance for developing young 
people's understanding' (Seixas, 2017: 61). It is this problem, which, more simply put, is about translating the theoretical constructs of historical consciousness into classroom practice, which my study tackled.

Linking the problem of historical consciousness to the topic of the relevance of history education, I define historical consciousness as 'a disposition to engage with history so as to make meaning of past human experience for oneself, or in other words, to make the historical past one's own' (Popa, in press). What does meaning making entail in historical learning? I conducted a comprehensive and systematic review of the literature to shed light on these questions, which helped to highlight three dimensions of historical meaning making in the scholarship (Popa, in press). First, students engage in making historical meaning by 'negotiating the presence of the past' (Popa, in press). This negotiation involves, on the one hand, experiencing the past as distant, and thus working with chronological understanding (Dawson, 2004; De Groot-Reuvekamp et al., 2014; Levstik and Barton, 2008), temporal understanding (Barton, 2002; Blow, 2011; Blow et al., 2012) and a temporal frame of reference (Blow et al., 2015; Lee and Howson, 2009; Wilschut, 2012). On the other hand, it involves experiencing the past as close, and thus becoming more and more familiar and personally involved with the past and its remnants, which occurs when students see, feel and morally respond to the past by engaging in 'history-making activities' (Ashton and Hamilton, 2009: 29), heritage topics (Gosselin and Livingstone, 2016; Henderson and Levstik, 2016; Jones, 2016) and ethically charged issues (Ammert et al., 2017; Chinnery, 2013; Seixas and Morton, 2013). In sum, negotiating the presence of the past is about performing a meaning-making balancing act between the temporal distances that separate the past and present, and the personal connections that tie the present to the past. Second, students engage in making historical meaning by 'inquiring about the past with the help of disciplinary and everyday habits of mind' (Popa, in press). Meanings about what happened in the past need to be transformed into history, that is, interpretations of historical traces and sources. A habit of mind guides students' focus and assists their perceptions, comprehensions and evaluations of historical material. For such meaning making, history students can primarily use investigations (Boix Mansilla, 2005; Lee and Shemilt, 2004; Saye, 2017), narrations (Kölbl and Straub, 2011; Levisohn, 2010; Rüsen, 2004; Wertsch, 2004; Zanazanian and Popa, 2018) and perspectives (De Leur et al., 2015; Lee and Shemilt, 2011; Retz, 2015). Each of these habits is grounded in the norms, discourses and practices of both the academic discipline and the surrounding culture. In sum, making meaning by inquiring about the past serves to interpret historical material. Third, students engage in making historical meaning by 'building a sense of historical being' (Popa, in press). Making meaning about the past and history provides opportunities to make meaning about who we are as individuals, how we see the future, and how we choose to act as agents in ongoing historical developments. For this, students can develop their awareness of their 'historical positionality' (VanSledright, 1998), notably by scrutinising widely shared and culturally mediated memories of the past, as well as inherited popular historical beliefs, uses of history, family histories, and darker aspects and minority perspectives in their national history (Clark, 2014; Grever et al., 2008; Levy, 2017; Nordgren, 2016; Peck, 2018; Wineburg et al., 2007). In sum, building a sense of historical being is about making meaning of who the student is as a person belonging to living history. These three dimensions of historical meaning making that emerged from the synthesis of my comprehensive literature review (Popa, in press) fleshed out my conceptualisation of historical consciousness, which I mention below and discuss in greater lengths elsewhere (Popa, under review). 


\section{Theoretical framework}

My conceptualisation of historical consciousness is motivated by its function within the context of teaching and learning. For this reason, it largely draws on Boix Mansilla and Gardner's (2007) and Nordgren and Johansson's (2015) conceptions of historical consciousness, who themselves borrow from Rüsen's $(2004,2005)$ theoretical elaborations. These scholars view historical consciousness, briefly put, as manifested in three abilities: to be sensitive towards the past, to understand the past and to represent oneself in relation to history. These abilities are respectively associated with a meaning-making process: experiencing historical temporality, interpreting historical material and orienting in practical life. Building on those scholars' conceptions, and in light of the results of my comprehensive review of the literature, the instructional model I developed (see Figure 1) outlines a learning trajectory that aims to cultivate students' disposition to engage with history so as to make meaning of past human experience for themselves (Popa, under review). I developed an instructional model that aims to cultivate students' disposition to engage with history so as to make meaning of past human experience for themselves (Popa, under review). It outlines the following learning trajectory (see Figure 1): by negotiating the presence of the past, both its closeness and its distance, students can engage in experiencing historical temporality, and thus cultivate their sensitivity towards the past; by inquiring about the past with the help of disciplinary and everyday habits of mind, namely investigations, narratives and perspectives, students can work on interpreting historical material, and can thus develop their understanding of the past; and by building a sense of historical being, students can engage in orienting in practical life, and thus develop their selfrepresentation in relation to history.

Underlying this envisioned learning trajectory are several theoretical assumptions about the nature of meaning making, learning, history and consciousness. First of all, what does it mean to make meaning? The concept itself has a variety of associations, which reflect centuries of scholarship and different epistemological and ontological paradigms. Drawing on Jarvis's (2018) comprehensive and interdisciplinary understanding of learning, meaning making in this study, simply put, consists of the

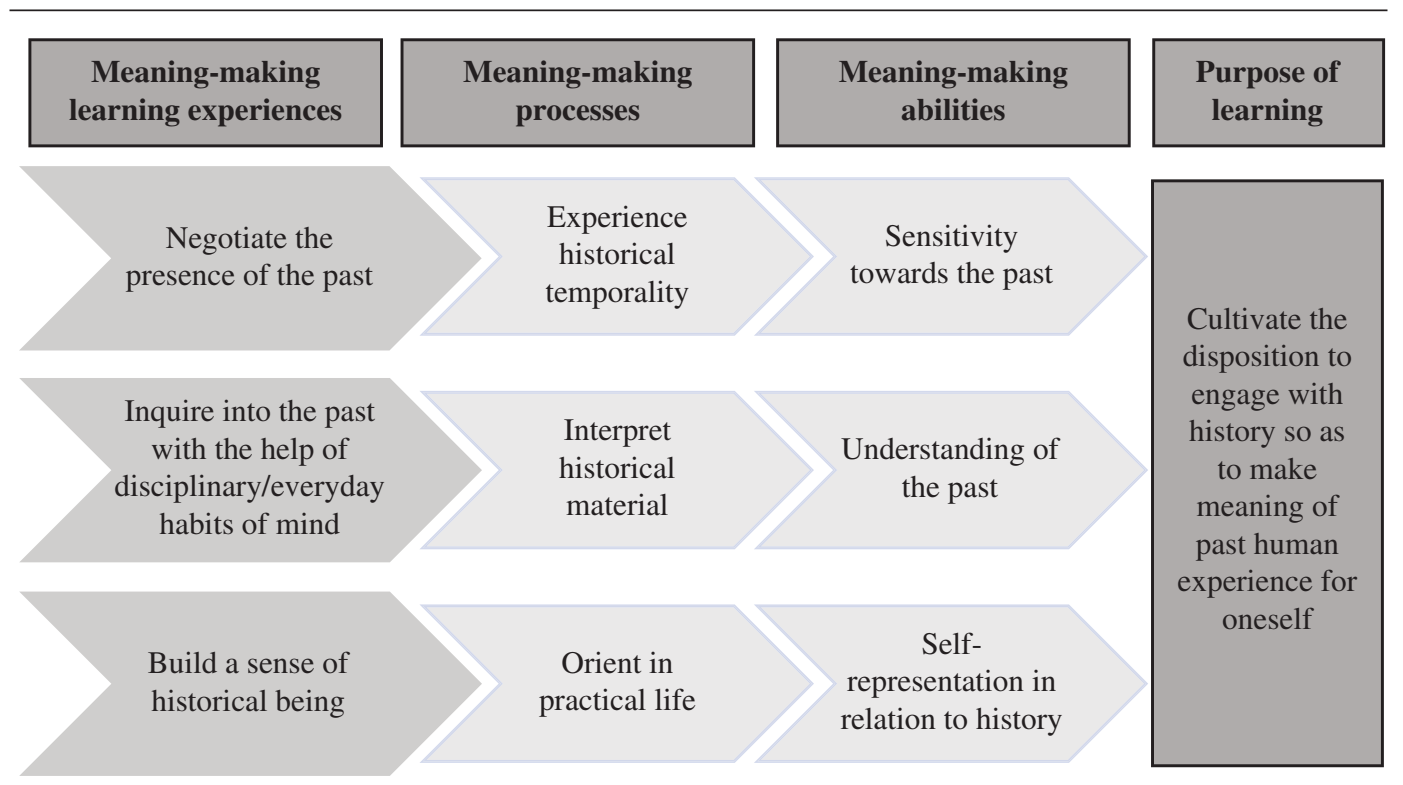

Figure 1: The intended learning trajectory for historical consciousness (source: author) 
transformation of experience, and learning is the activity of changing the meaning of experience, and thus the person who learns. Since it is a fundamental phenomenon of our everyday lives and conscious interaction with the world, it helps us constructively make sense of our experiences of social situations in relation to our life-world, and helps us grow by developing more experience, thus 'learning to be me' (Jarvis, 2018: 24). Consequently, for the purposes of my study, I align with scholars such as Becker (1932), Osborne (2006), Lee (2011) and Seixas (2012), who suggest that history broadly represents a lens through which we, as human beings, can be aware of and understand remnants of the past that people over time have preserved and ascribed with meaning. Thus, it has a transformative power that enables us to make meaning that connects us to a world beyond our own existence. Accordingly, my view of consciousness, borrowed from Boix-Mansilla and Gardner's (2007) account of neuroscientist Antonio Damasio's theory of consciousness, refers to the construction of the subjective mind in mutual interaction with the world. It involves a complex, integrated combination of embodied mental processes, such as memories, knowledge, reflection, motivations, feelings, emotions and expectations, that relate our experiences of the world to our changing autobiography (Damasio, 1999, 2010). As such, students come to their history classes already possessing historical consciousness, which has been constructed through formal and informal learning. The aim of cultivating this disposition in school history is to enable students to engage in the three processes, and to develop the three abilities of historical consciousness in a focused and constructive manner.

\section{The study}

The discussion presented in this article is drawn from a classroom experiment inspired by educational design research (Kelly et al., 2008; McKenney and Reeves, 2019; Plomp and Nieveen, 2013; Sandoval, 2014), in which a unit was developed to apply the instructional model of historical consciousness. As Clark and Grever (2018: 189) point out, 'much of the extant research into the educational dimensions of historical consciousness is still at a theoretical, rather than empirical, stage'. Although there are a few studies that have investigated how the concept might be used in the classroom (see Blow, 2011; Eliasson, 2011; Rogers, 2008), they are mostly focused on outcomes of learning. The purpose of my study was to develop and implement an instructional model of historical consciousness and to investigate the process of learning.

Participants in this study consisted of one high-school history teacher, Michael, and the students enrolled in the Grade 11 Advanced College Preparatory (ACP) US history course that he was teaching at the time. The school at which he taught was a public high school located in the suburban circle surrounding Boston, Massachusetts (USA), with a population of about eighty-five thousand. Participants were purposely selected through a mixture of purposive sampling for the teacher (which requires a number of strategic choices about where, how and with whom the research is conducted) and convenience sampling for the students (including those who are the most eager and able to participate in the study) (Miles et al., 2014). Because of the collaborative nature of my methodology, I was interested in recruiting and working with a teacher who would: show a general interest in the role of history in our presentday society; be committed to reflective teaching practices and constructivist learning; and be willing to design and experiment with new lesson plans, teaching activities and materials. The selection of the student participants was based purely on the fact that they were enrolled in a history course taught by the selected teacher. Michael chose the class himself, and all 24 students enrolled were invited to participate in the study. I received a total of 21 consent and assent forms. Whether or not a student participated 
in the study did not affect how they took part in class activities. Only data produced by participating students were used for the research. Once Michael agreed to be part of the study, I asked for and obtained permissions and approvals to conduct my study in his classroom from both the school principal and the school board. The inquiry was approved by my university's institutional research ethics board prior to data collection. Ethical considerations, standards of conduct and procedures firmly informed the study throughout the research process.

The data collected that concern the topic of this paper consist of field texts and student work. To gain information on meaning-making activity, I conducted participant observations for all of the unit's 10 lessons. In doing so, although my presence in the classroom community was evident to all, I recorded my observations as an outsider. During each lesson, I sat at a desk and took notes in my notebook. On the left side of the page, I recorded a descriptive, narrative running log of participant words and actions. On the right side of the page, I recorded my emerging thoughts and impressions about what I was observing. In addition to on-site notes during lessons, I also wrote off-site post-observation reflections in my notebook. I audio-recorded each lesson with a digital audio-recording device. I transcribed the recordings myself, on my personal computer, including as much information about verbal and non-verbal aspects of talk and non-word utterances as I deemed relevant. Additionally, I collected student work in the form of portfolios, which consisted of 35 pages of pedagogical material for classroom activities and homework. The portfolio, a tool for both learning and data collection, was specifically created for the purposes of the unit. It contained: homework assignments, worksheets to guide and support in-class activities, vocabulary sheets listing and defining key terms and concepts to enhance understanding of material covered in class, and formative self-assessment rubrics for students to reflect on their learning. Michael and I developed the content of the portfolio, most of which was drawn from material and resources freely available on the internet.

As mentioned in the introduction, this article focuses on a specific aspect of the study's findings. While I used sociocultural discourse analysis and constant comparative analysis to examine student learning in classroom activity and student portfolios, I noticed my results left out what I had deemed to be insightful facets of historical consciousness in my field notes and analytic memos. While I was finding interesting similarities across the data set, which revealed students' cognitive, affective and sociocultural engagement in the three abilities of historical consciousness and their processes, aspects of student meaning making that overlapped or neighboured each other in their original context were being left out. Because of this limitation, I decided to turn to found poetry in an attempt to better represent the subtleties of student meaning making. Found poetry can be described as 'the rearrangement of words, phrases and sometimes whole passages that are taken from other sources and reframed as poetry by changes in spacing and/or lines (and consequently meaning), or by altering the text by additions and/or deletions' (Butler-Kisber, 2010: 84). This method comes from arts-based or arts-informed qualitative inquiry, which constitutes a 'paradigm orientation and practice' that opens up 'possibilities for alternative perspectives, modes, media, and genres through which to understand and represent the human condition' (Knowles and Cole, 2008: xii). An artful rendering of qualitative data has several characteristics according to Eisner and Barone (1997); notably, it is 'expressive' and it is communicated in 'contextualized and vernacular' language. In this sense, poetic analysis helps to uncover and illuminate 'what otherwise might go unnoticed' (Butler-Kisber, 2002: 5), helping to review, synthesise and deliver material in an evocative way. 


\section{Findings}

According to Butler-Kisber (2010: 85), 'there is no template or prescribed approach for creating found poetry'. In this case, I started with field notes and analytical memos, written during the data collection and analysis phases. In these notes and memos were salient words and phrases, or poignant metaphors and messages, which thus represented 'occasions for poetry' (Sullivan, 2009, cited in Butler-Kisber, 2010: 90). Once I pulled out a word, phrase, message or metaphor from my logs, I began to read back and forth across the spoken, written and/or visual data extract in which it appeared, and also in and out of data sources, to get a better sense of the events and experiences in which it was embedded, as well as the discursive nuances, emphases and different layers surrounding that word, phrase, message or metaphor. Some of these occasions for poetry extended across different people and data sources, while others settled within a single student or source. I selected the specific data sources from which to develop the poetry based on this creative process. When I had drawn enough substance to flesh out these different occasions for poetry, I then proceeded to craft a poem. I wrote stanzas combining wordings and images from the data. I stayed as close to the raw data as possible to immerse the reader in the participants' words and world. The only alterations I made were for aesthetic purposes. For instance, I added or slightly modified words when I deemed it would help with the structure, flow or rhythm of the text, such as substituting 'World War Two' for 'WW2', adding 'the' before a word, substituting 'its' for 'their', or changing a verb tense such as 'made' to 'makes'. I went through several drafts of poems, and decided that they were final when they brought to life the occasions for poetry that I was struggling otherwise to communicate.

\section{Poem 1: All these things sometimes come together in talking about this}

Often in World War Two,

We're told of the Nazis, Hitler, the war, men,

But we're not told of the suffering, of the children,

And that's really important too.

It is very worn out, its arms and legs

Have been reattached. It's a KZ doll.

It belonged to Helen Klein, imprisoned

At Ravensbrück concentration camp for women.

It has fair skin and has blue eyes.

The wear and tear of the doll,

Like the fading in the child's innocence

And the corruption it had to face day to day.

My dream is to become an army nurse.

Nurses have played different key roles,

Throughout history, saving soldiers

Even in the worst scenarios.

All military movies, I cry,

Cause my dad was in the military.

They didn't have any help, when they came back to normal life,

Expected to jump back into the normal ways of living. 
Like my dad, when he would drive, all the time,

He would look up for helicopters, checking.

War is never the answer.

It's traumatising. World War Two

Must have been most traumatising

To the youth.

I wish I knew why the doll lost her arms and legs,

And I wish I knew the importance of the doll to the girl.

Walk together with Helen Klein as she grows up

To be taken to a concentration camp.

I cannot possibly relate to her suffering.

This first poem originated from a memo from my classroom observations. I had picked up on what one student shared with their group about the object that they had brought in for a show-and-tell activity: a photograph of a KZ doll from the Holocaust section of the online collection of the International Museum of World War II (https:// museumofworldwarii.org/collection/holocaust/kz-doll-hr/). The poetic nature of what this student shared moved me. However, it did not find its way into my analysis, because of the isolated nature of the occurrence. Going over my classroom transcripts, I began to see something of a connection between how this student articulated meaning about the doll in the small group chat and the content of the student's portfolio, where they elaborated on the KZ doll and thought through ways in which the war was connected to their life (see Figures 2 and 3).

I found evidence of affective personal connections to remnants of the past students feeling touched and moved by its traces - but also connections between

(1) what is it? (name, color, shape, size, smell, taste, sound, who, where, when)

The object found is a $k 7$ Doll, it is very worn out. its arms and leges have been reateached it is fair skinned and has bue eyes.

(2) what do you know / don't know about it? (origin, purpose, story)

The doll belonged to Helen kizin, wasimprisoned at Ravensbruck concentration camp for

women. I wish I knew why the dolls lost her arms and wege and in is ienew the impor tance of the doil (3) why did you choose it? how do you think it is related to wWil? to the gir 1 I chose the doll because it represents the

children. Most of the time when talked about Wwil we are told of the nazis, titter, war and

the sewish persecution. Wril must haje been most (4) what emotions do you feel when you see or think about it? traumanzing I cannot possibly relate to the suffering to the youtheof the girl. As I kept $100 \mathrm{king}$ at the image cuted we could sce the cloll as a symbol outhe girls innowence and like tha doll is tading Bring your image or object to class on Friday, March 9.

You will have one minute to tell your classmates about it!

to day

Figure 2: Scanned image of Portfolio 17, page 5 (source: author) 


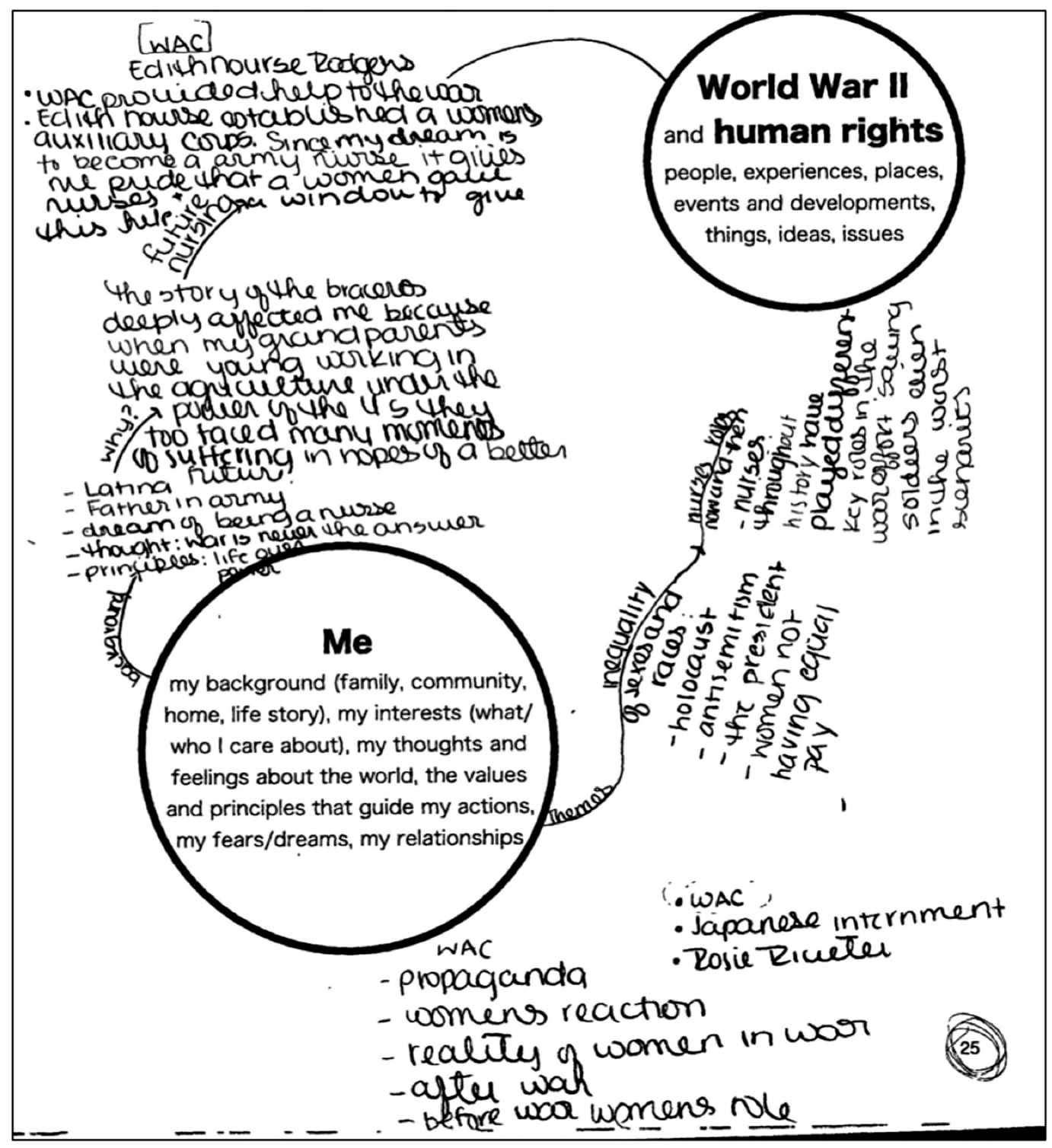

Figure 3: Scanned image of Portfolio 17, page 25 (source: author)

history and their own biographical narratives. The title reproduces something Michael said during a lecture about the Holocaust and other human rights abuses, which I thought was reflected in this student's meaning making:

You know as a teacher it's hard for me sometimes too, to talk about what happened, because it's so, um, just unbelievably cruel. And my own background in terms of being Czech, and Polish, and gay, and all these things sometimes come together in talking about this.

With this poem, I wanted to communicate the notion that who we are influences what we see in history, how we relate to it, and how it helps us talk about ourselves, in ways that are at the same time deeply personal and also unanimously understood. Overall, the poem attempts to illustrate how one student found meaning in the past and created new meaning for the present through experiencing the past as being close, and through building a sense of historical being, in light of personal life experiences that have marked them, and of dreams that define them. 


\section{Poem 2: I have a duty}

So many people

Went along with this

And didn't try to stop it.

So many people

Died because others thought

They could just take

Their rights away.

Some people had

No hesitation

To drop atomic bombs.

Some people will go

To extremes to keep their nation safe,

Even if they know

What they are doing is wrong.

Can't get my mind around it.

The Hess Gold Nazi pin,

For the first one hundred

Thousand members,

A circle with a gold border and then grey and white stripes,

The colours caught my eye,

And then an inner white circle with a black swastika.

The Golden Party badge.

The party was branding their people

With these pins.

It's crazy.

So many people joined the Nazi Party

And wore these with pride.

It makes me frustrated.

The hatred in the world.

It makes me sad that people were being killed,

And disturbed - that they could kill people this easily,

For bad reasons in such large amounts

So quickly.

Zyklon B,

A cyanide-based pesticide,

Used to kill mass groups of people

More efficiently.

I don't understand how humans can do those types of things to other humans.

I feel fortunate that my grandfather managed to survive.

I don't understand how people deny that it happened.

People make mistakes,

And even if a sorry doesn't fix what happened,

It's one of the best things we can do. 
Don't forget the horrible things

That have happened.

Realise where we've gone wrong,

Learn from our mistakes.

Acknowledge

We have harmed and continue to harm you,

And we are trying to change

For real this time.

Discrimination against black people.

Easy targets because of the colour of their skin.

Discrimination against women by men.

Treated like second class citizens, like the second string.

Fight against discrimination,

Intolerance to diversity.

Try to see past labels.

Fight back with knowledge.

Many of the problems during World War Two,

With race relations, women's rights, LGBT rights

Are slowing down today thanks to the fact

That history has kept these events

As an awareness.

But we're still fighting for them.

As a young adult,

Knowing these events and their causes

Can help me have an idea

Of their consequences.

I have a duty

To spread positivity

And anti-discrimination,

To attempt to make the world

A better place.

This poem brings together multiple voices from a wide variety of sources. It represents the difficulty some students encountered in grasping the scale, nature and purpose of wartime hatred and wrongdoings, and their ensuing desires not to perpetuate similar actions. Extracted from their context and isolated in quotations as I conducted thematic analysis, students' words lost their power. Uniting them in the form of a poem helped to recreate a context for the unit of instruction; one of being confronted with facts and artefacts that they struggled to comprehend from a moral point of view, but to which they nonetheless responded, trying to make sense of them. This represents what Jarvis (2018) calls a 'state of disjuncture', the basis of any experience of the world that requires meaning to be made. The poetic format also helped to reinvest students' words with the rich emotion and the condemning attitude that struck me at first, but that seemed mollified in my thematic analysis. Using habits of mind such as perspectives and narratives helped the students to 'resolve' the state of disjuncture in a constructive way, which, according to Jarvis (2018), constitutes the core of the existential dimension of learning, because the learner thus integrates meaning into their life history and identity. As such, this poem offers a glimpse into 
the intricate processes of interpreting historical material and orienting in practical life through history.

\section{Poem 3: Do we feel we've answered the question?}

The one, over there,

I think it's A. It's C.

Oh, hold on, G could be

The first. That one is 4 ,

I agree.

That's funny, I like this one.

No not D, What about I?

None of these fit well.

We have three left.

What did you put for I?

What is this?

Try it on!

So cool!

This actually looks like...

Can you believe what they were doing?

Why are they grouped together?

The little things here ...

Wait when was that?

What does it look like?

What is that symbol?

What's that thing dangling?

Guys, if I remember correctly ...

What do you think of ...

Where's Buna?

Who's the 'we'?

So is this the Nazi and the Soviet Union?

That's Hitler and Stalin.

That's Mussolini mind you.

Yikes, wait,

That's Hitler.

The Nazis

Were terrible.

You forgot the Japanese

Were much, much worse.

Yeah but we're not talking about the Japanese here.

If I had the choice, I wouldn't drop it.

I would've stopped the Manhattan Project entirely,

Yeah but think about it,

Without those discoveries,

A lot of stuff today we're using ...

It was really scary, terrifying, traumatising.

Maybe it wasn't so dramatic. 


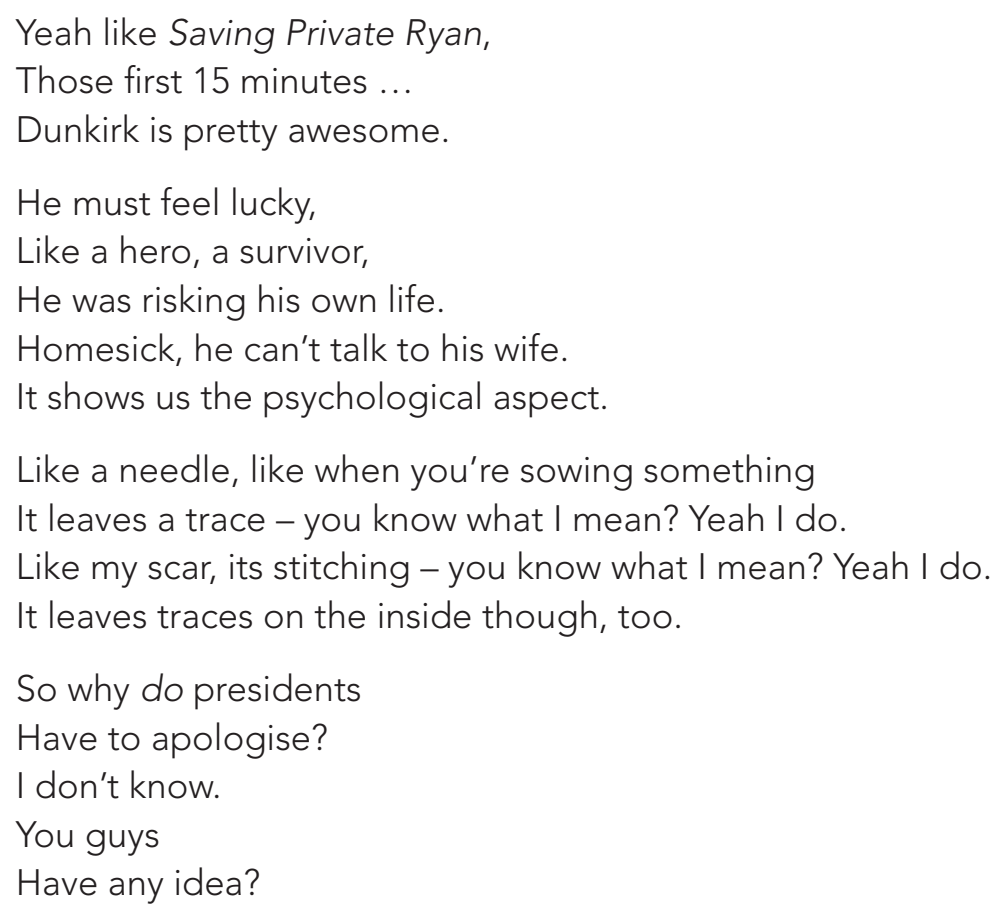

This poem represents the spirit of intellectual liveliness and curiosity that I perceived when observing and listening to students interact as they engaged in group inquiry tasks. In these situations, students were given instructions to complete a task that required them to examine historical sources and answer handout questions. They did so independently, although they always had clear instructions to guide them, and Michael, the textbook and the internet at their disposal. I heard students do many things: question the material and each other's perspectives; establish a shared knowledge base; try to come up with the correct answer or a better explanation; debate ethical dilemmas; share personal opinions or anecdotes; have fun touching or looking at the material; build interpersonal relations; imagine and interpret people's experiences; and wonder about the purpose of people's actions. The reason I felt compelled to translate these moments into a poem is that my analysis so far had not been able to represent and describe them in an intelligible way. This is likely because of the nature of the data: they were disparate comments heard arbitrarily, and recorded without any narrative or logical thread, and thus unfortunately discarded in my analysis to focus instead on whole-class discussions, where I found structure and coherence. It would have been a shame to leave them out of my analysis, however, as my poem shows, because they reveal how meaning making was based on a genuine collaborative effort in, and a relative comfort with, having intellectual autonomy over the inquiry process and the construction of knowledge. These situations, moreover, seem to provide students with a sort of testing ground for their reactions and reasoning; in fact, what I overheard during group talk often came up during whole-class discussions. Most of all, with this poem, I wanted to communicate the power and possibilities of student questions in learning. The title of the poem is in fact a question posed by one student to their classmates during a group inquiry situation. As Jarvis (2018) argues, a 'sense of unknowing' stimulates the experiential dimension of learning. Due to the overwhelming number of questions and lack of answers, this poem might leave the reader feeling disoriented. This was indeed my intention as a writer, because I wanted to share how I felt as a researcher, capturing bits and pieces of student talk, which in the moment appeared crude or insignificant, but which, later on, proved to be essential to meaning making. 


\section{Poem 4: Asian}

Korea peninsula.

Japanese occupation.

Korea under Japanese rule

Began with the end

Of the short-lived Korean Empire in 1910

And ended at the conclusion of World War Two

In 1945, liberated with Japan's surrender.

The Japanese colonial government

Oppressed the Korean people

With the help of the Joseon governor

And the administration,

Legislation,

Suppression

Of independence movements,

Discriminatory policy,

Law enforcement,

The military.

The Korean people

Fought against

Japanese colonial rule

And tried to regain the country.

1931

Kim Gu organised

The Korean Patriots' Association

And executed major Japanese people.

April 1932,

Many Japanese people rushed to Hongkou Park in Shanghai

To commemorate the victory of the Japanese army

In the conflicts with the Chinese army.

Yoon Bong-gil went to the park,

Threw a bomb at the podium.

Several Japanese people collapsed

In the wake of the explosion.

Yoon was arrested and killed.

My grandfather's sister passed away during

The war

By starving.

Many people from

My grandfather's generation,

They have this aversion

In them.

This final poem deals with a very specific aspect of student meaning making. Using Jarvis's (2018) lens, it appears that the student is 'internalising' the history of the Second World War by making meaning through a specific community's practices of remembrance, and their own social identity as a member of that community. 
In contrast to the previous poems, the content for this one is drawn exclusively from a single student's portfolio and a single task. The task consisted of a brainstorm activity to get students to start thinking about their final project for the unit. Specifically, it asked students to reflect on how the history of the Second World War is connected to who they are and the life they are living or expect to live in the future. This student's sheets (Figures 4 and 5) caught my attention, because the student was one of few

(Japanese Iccupation)
O2k1175x-11 Japanese korea $(1910-1945)$

korea under sapanese rule betan with the end of the short lived korean empire in 1910 and ended at the conclusion of WW2 in 1945.

Japanese occupation $(8 / 2911910 \sim 8 / 151945)$ is in the history of

korea's modern histony of South korea as one of the key when

it was by. On time, under the korean peninsula and its adjacent

islands were Japanese colonial rule.

Generally, this period is divided into three periods according to Japan's ruling policy on the Korean peninsula : the Militany police Controle, and the Cuttural controls. On Avoust 15, it was liberated with Japanis surrender lbut it tied the knot with Japan and severed relations With the two countries. 24

Discriminatony policies against koreans and suppression of independence movenk took place.

Figure 4: Scanned image of Portfolio 4, page 24 (source: author)

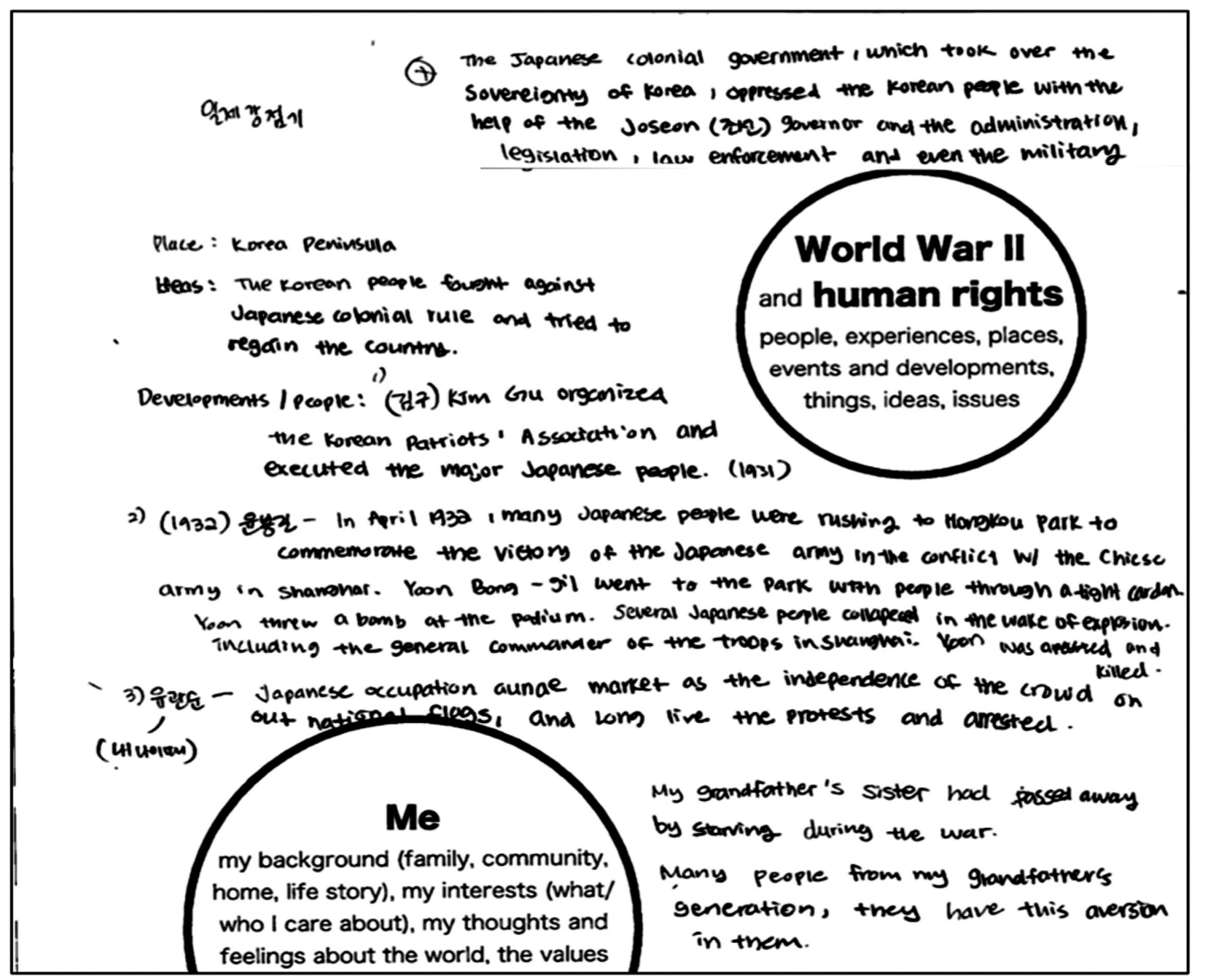

Figure 5: Scanned image of Portfolio 4, page 25 (source: author) 


\section{One way my life connects to the history of WWII and human rights is: Assian.}

Figure 6: Scanned image of Portfolio 4, page 35 (source: author)

to complete the task seriously. A possible reason why most students either did not complete the assignment or did so in a rather superficial way is that it was set as homework and given at the end of the unit, and it was thus not reviewed in class; there were no expectations to complete it. Another possible reason is that, for students, self-representing themselves in relation to history was not an established norm of the classroom community's ways of thinking and learning about the past, and students might have needed better scaffolding leading up to this kind of individual activity, or constructive feedback following it. This student, however, filled the two pages dedicated to the task.

More importantly, it was one of the only times that a student demonstrated an ethnic identity in speaking about history, with the exception of students of Jewish background. The writing in Korean is telling in this respect. What resonated with me in this student's assignment is how they wrote about the past in a way that is simultaneously personal (bringing in their family history and ethnic/cultural identity) and impersonal (listing historical facts and events), thus balancing the distance and closeness of the past. The poem attempts to express this, but also how the student relates history to their Asian background, and thus articulates meaning about the Second World War that has implications for the purpose of navigating everyday life. The title represents something that the same student wrote in a second brainstorming assignment (Figure 6). This task required students to pick one connection that they had made in the first brainstorm task, and to expand on how it shapes their sense of who they are. I found that there was something poetic about the single word appearing on the line, all by itself. To me, it communicated social identity and temporal bearings, and the power of its bareness, in contrast to the overwhelming information in the first brainstorm task, moved me. The poem juxtaposes the sober or detached quality of the label-like 'Asian' with more engaged or denunciatory comments. Again, this serves to shed light on a way of negotiating the presence of the past and building a sense of historical being.

\section{Discussion}

Classrooms can be sites of rich and diverse meaning making. This was the case in the unit I studied, as the results of ethnographic investigation and triangulated research methods revealed. However, meaning-making processes can be difficult to observe. For one, they are dynamic and intersubjective. That being said, investigating processes of learning in which meaning making occurs can provide a refreshing outlook on education, and perhaps a much needed one in history education. Indeed, in the attempt to operationalise historical consciousness for educational purposes, several scholars have recently adopted a competency-based approach, building on the literature in narrative competence and/or historical thinking to develop models for historical sense making. Curricular reforms and research that have taken this direction can be found notably in Canada (Duquette, 2015; Seixas, 2015); Austria, Germany and Switzerland (Körber and Meyer-Hamme, 2015; Waldis et al., 2015) and Sweden 
(Eliasson et al., 2015). The competency-based approach undoubtedly promotes an important form of learning, that is, acquiring the knowledge, skills and attitudes needed to resolve domain-specific problems using domain-specific ways of reasoning and doing (for example, analysing sources, formulating questions, constructing arguments, using conceptual knowledge and applying procedural knowledge). However, several researchers have expressed concerns about how it possibly reduces historical consciousness to a cognitive-epistemological skill set that views history as a distinctly modern and Western mode of thinking and research, and tends thus to discount the affective, sociocultural and identity-related dimensions of historical sense making in learning (Friedrich, 2014; Grever and Adriaansen, 2019; Nordgren, 2019; Thorp and Persson, 2020). Some scholars, namely Van Straaten et al. $(2015,2018)$, have taken a different path in the effort to translate historical consciousness into educational practice so as to make the subject more relevant to students' lives. With the scope of developing learning objectives and teaching strategies to help students 'recognize and experience what history has to do with themselves, with today's society and their general understanding of human existence', Van Straaten et al. (2015: 4) emphasise personal fulfilment, rather than competence. The work discussed in this paper similarly argues that an approach focused on personal fulfilment in historical learning is a more promising direction in operationalising the construct of historical consciousness; it does so by highlighting processes over outcomes when it comes to students' development of meaningful relations with the content of learning.

Furthermore, meaning-making processes can be difficult to render without appropriate techniques. The poetic interpretation of learning in this study provided 'an alternative form of representation' (Patrick, 2016: 397). Found poetry arguably consists of a connecting or contextualising analytic strategy in qualitative research, which, according to Maxwell and Miller (2008: 462), focuses on 'contiguity-based relations' that involve perceiving actual connections between things in an actual context, such as juxtapositions in time and space, relations among parts, and influences. By contrast, categorising strategies of qualitative data analysis, such as coding, focus on relationships of similarity and commonality, and thus involve perceiving features of comparison between objects, which are mostly independent of context (Maxwell and Miller, 2008: 462). These are two 'fundamentally different kinds of relationships between things' (Maxwell and Miller, 2008: 462). As a contextualising analytic strategy, arts-informed research methods, and found poetry specifically, can be appealing to research in history education, especially when it comes to portraying complex, multilayered contexts, and revealing their hidden links and nuances. Contextualising strategies stay as true to contexts as possible by emphasising, as Butler-Kisber (2010: 97-8, citing Sullivan, 2009) suggests, 'concreteness' (that is, bringing an image to life to offer the reader an embodied experience); 'emotion'; 'unresolvedness' (that is, embracing mystery, paradox, questions and ambiguity); and 'associative logic' (that is, providing connections and coherence, despite the lack of a linear structure, and building on internal tensions). Looking at Poem 1, for example, the image of the KZ doll and the empathy felt for its former owner become deeply tangible (concreteness) as the student makes meaning of it. In so doing, it gives us - the reader of the poem, and receiver of meaning - a window into the student's affective response towards, and cognitive struggle with, trauma, sadness, suffering and cruelty (emotion). The poem, moreover, does not answer a question, resolve a learning task or take a stance on a topic; rather, it espouses a puzzle - that is, why the destruction of ordinary, innocent people's lives for the purpose of war is tolerated (unresolvedness). Finally, the poem serves as a vehicle to transport meaning in other realms, namely through the figure 
of the soldier father, widely known military films, and the dream of becoming a war nurse (associative logic). These are the different ways in which found poetry consists of a contextualising analytic strategy. By contrast, one of the main themes to emerge from the constant comparative analysis of meaning making in classroom talk and student work was that the difficult past was made to sound familiar, more precisely by invoking cultural references, by evoking feelings, emotions and memories, and by making analogies to present actions of discrimination, vulnerability and injustice. Poem 1 is undoubtedly related to this theme, and it speaks to those three sub-themes in several ways. However, categorising the same data that were used for Poem 1 strips the research material of its speaker and its context, and thus relinquishes subtleties at the expense of commonality. The reference to military films is no longer associated to crying; to be part of the first sub-theme, it becomes just another occurrence of a cultural artefact. The remnants and experiences of Helen Klein no longer offer a portal to talk about personal dreams and family stories; instead, to be part of the second subtheme, they become an instance among others of the horrors of the Holocaust. The genuine concern for the trauma of war no longer speaks to the suffering of children and the metaphor of fading or stolen innocence; to be part of the third sub-theme, it is rather classified as a reference to soldiers coming back from combat in Iraq with posttraumatic stress disorder. Research in history education that seeks to make the elusive qualities of students' lived experiences, thinking, reasoning, affective responses and imagination more tangible could greatly benefit from this method. Found poetry and other arts-informed research methods can also be appealing to research in history education in cases where the researcher seeks to develop differential interpretations of words, to establish a connection between data that otherwise appear disparate from the point of view of categorising analytic strategies, and to produce results that resonate with the reader.

\section{Conclusion}

Research to date that strives to understand how the construct of historical consciousness can be applied to educational practice has, for the most part, favoured a competencybased approach. In this article, I have explored another approach, reflected in a unit of instruction based on an innovative instructional model, which was focused on learning as meaning making, and historical consciousness as a disposition to make historical meaning for oneself. In trying to describe and understand the process rather than the outcomes of learning, the inquiry revealed how students who took part in the study engaged in meaning making in deep and diverse ways through cognitively, affectively and socioculturally engaging in the negotiation of the presence of the past, inquiring about the past with the help of disciplinary and everyday habits of mind, and building a sense of historical being. Found poetry helped to shed light on these processes. The findings presented here suggest that there are facets of student learning that thematic analysis could not capture. Namely, I have asserted that found poetry helped render the subtleties of meaning making in the classroom in a way that enables us as researchers to better grasp how participants expressed meaning, the relation between those meanings and their context, and to identify with the meaning makers. Such immersion in students' words and worlds can be useful for educational research that studies how to make school history more meaningful and relevant to students. Used concomitantly with sociocultural discourse analysis and constant comparative analysis, it proved to be a productive way of communicating the data analysis. That being said, one limitation of the study is that it represents a thick description of only 
one case, and even though the findings are likely to resonate with other educators and transfer to other settings, other design classroom experiments are needed to fully assess its contributions. Further research in this area could investigate different planning and teaching strategies, learning activities, classroom environments, material and resources, and forms of assessment that promote meaning-making processes of historical consciousness. Another line of inquiry in this area could look at the unconstructed aspects of meaning-making processes involved in historical consciousness, or, in other words, that which is avoided, hidden, silenced, inhibited, taken for granted and so on. Indeed, a limitation of my found poetry analysis is that I sought to illuminate the meanings that had been constructed; but what do we make of meaning that does not find its way to the analysis in the first place? These different avenues of research would be more design-based and empirically driven than the conversation on historical consciousness in history education has allowed for so far, but they would help the field advance on the issue of applying this important concept to practice.

\section{Acknowledgements}

I wish to thank the participants of this study for opening their classroom to me. I am also grateful for Dr Paul Zanazanian's (McGill University) constructive feedback on draft versions of the manuscript.

\section{Funding}

This work was supported by the Fonds de recherche du Québec - Société et culture under Grant 197281.

\section{Research ethics statement}

The author declares that the research discussed in this paper has been approved by McGill University's Research Ethics Board Office under the REB File \#: 312-1217.

\section{Conflicts of interest statement}

The author declares no conflict of interest with this work.

\section{Notes on the contributor}

Nathalie Popa holds a PhD in educational studies at McGill University, Canada. Her research interests focus on historical consciousness, and teaching and learning practices in history. She has a BA and an MA in history. As part of her doctoral studies, she was a visiting student at Harvard Graduate School of Education, USA, and a research intern at Karlstad University, Sweden.

\section{References}

Ahonen, S. (2001) 'The past, history, and education'. Journal of Curriculum Studies, 33 (6), 737-51. https://doi.org/10.1080/00220270110061729.

Ammert, N., Edling, S., Löfström, J. and Sharp, H. (2017) 'Bridging historical consciousness and moral consciousness: Promises and challenges'. Historical Encounters, 4 (1), 1-13. Accessed 14 July 2021. https://researchportal.helsinki.fi/en/publications/bridging-historical-consciousnessand-moral-consciousness-promise. 
Angvik, M. and Von Borries, B. (eds) (1997) Youth and History: A comparative European survey on historical consciousness and political attitudes among adolescents. Hamburg: Korber-Stiftung.

Ashton, P. and Hamilton, P. (2009) 'Connecting with history: Australians and their pasts'. In P. Ashton and H. Kean (eds), People and Their Pasts: Public history today. London: Palgrave Macmillan, 23-41.

Barton, K.C. (2002) "“Oh, that's a tricky piece!": Children, mediated action, and the tools of historical time'. Elementary School Journal, 103 (2), 161-85. https://doi.org/10.1086/499721.

Becker, C. (1932) 'Everyman his own historian'. The American Historical Review, 37 (2), 221-36. https://doi.org/10.2307/1838208.

Blow, F. (2011) '"Everything flows and nothing stays": How students make sense of the historical concepts of change, continuity and development'. Teaching History, 145, 47-55.

Blow, F., Lee, P. and Shemilt, D. (2012) 'Time and chronology. Conjoined twins or distant cousins?'. Teaching History, 147, 26-34.

Blow, F., Rogers, R., Shemilt, D. and Smith, C. (2015) 'Only connect: How students form connections within and between historical narratives'. In A. Chapman and A. Wilschut (eds), JoinedUp History: New directions in history education research. Charlotte, NC: Information Age Publishing, 279-315.

Boix Mansilla, V. (2005) 'Between reproducing and organizing the past: Students' beliefs about the standards of acceptability of historical knowledge'. In R. Ashby, P. Gordon and P. Lee (eds), Understanding History: Recent Research in History Education. London: Routledge, 98-115.

Boix Mansilla, V. and Gardner, H. (2007) 'From teaching globalization to nurturing global consciousness'. In M. Suarez-Orozco (ed.), Learning in the Global Era: International perspectives on globalization and education. Berkeley: University of California Press, 47-66.

Butler-Kisber, L. (2002) 'Artful portrayals in qualitative inquiry: The road to found poetry and beyond'. Alberta Journal of Educational Research, 48 (3), 229-39. Accessed 14 July 2021. https://core.ac.uk/reader/236134003.

Butler-Kisber, L. (2010) Qualitative Inquiry: Thematic, narrative and arts-informed perspectives. Los Angeles: Sage.

Carretero, M., Berger, S. and Grever, M. (eds) (2017) Palgrave Handbook of Research in Historical Culture and Education. London: Palgrave Macmillan.

Chinnery, A. (2013) 'Caring for the past: On relationality and historical consciousness'. Ethics and Education, 8 (3), 253-62. https://doi.org/10.1080/17449642.2013.878083.

Clark, A. (2014) 'Inheriting the past: Exploring historical consciousness across the generations'. Historical Encounters: A Journal of Historical Consciousness, Historical Cultures, and History Education, 1 (1), 88-102. Accessed 14 July 2021. https://opus.lib.uts.edu.au/ bitstream/10453/35522/3/2013005288.pdf.

Clark, A. and Grever, M. (2018) 'Historical consciousness: Conceptualizations and educational applications'. In S.A. Metzer and L.M. Harris (eds), The Wiley International Handbook of History Teaching and Learning. Hoboken, NJ: Wiley-Blackwell, 177-201.

Clark, A. and Peck, C. (2019) Contemplating Historical Consciousness. Notes from the field. New York: Berghahn Books.

Damasio, A. (1999) The Feeling of What Happens: Body and emotion in the making of consciousness. San Diego, CA: Harcourt.

Damasio, A. (2010) Self Comes to Mind: Constructing the conscious brain. New York: Pantheon Books.

Dawson, I. (2004) 'Time for chronology? Ideas for developing chronological understanding'. Teaching History, 117, 14-24. Accessed 14 July 2021. www.history.org.uk/secondary/ resource/102/time-for-chronology-ideas-for-developing-chronolo.

De Groot-Reuvekamp, J.M., Van Boxtel, C., Ros, A. and Harnett, P. (2014) 'The understanding of historical time in the primary history curriculum in England and the Netherlands'. Journal of Curriculum Studies, 46 (4), 487-514. https://doi.org/10.1080/00220272.2013.869837.

De Julio, A. (2019) 'How can we truly bring history to life?: Reflections and takeaways from the Annual Conference 2019', 15 April. Accessed 14 July 2021. www.euroclio.eu/tag/bringinghistory-to-life/.

De Leur, T., Van Boxtel, C. and Wilschut, A. (2015) '"Just imagine...": Students' perspectives on empathy tasks in secondary history education'. International Journal of Historical Learning, Teaching and Research, 13 (1), 69-84.

Duquette, C. (2015) 'Relating historical consciousness to historical thinking through assessment'. In E. Ercikan and P. Seixas (eds), New Directions in Assessing Historical Thinking. London: Routledge, 51-63. 
Eisner, E.W. and Barone, T. (1997) 'Arts-based educational research'. In R.M. Jaeger (ed.), Complementary Methods for Research in Education. Washington, DC: AERA, 73-99.

Eliasson, P. (2011) 'In search of historical consciousness - A classroom research project of history education'. In K. Nordgren, P. Eliasson and C. Rönnqvist (eds), The Processes of History Teaching An international symposium held at Malmö University, Sweden, March 5th-7th 2009. Karlstad: Karlstad University Press, 43-67.

Eliasson, P., Alven, F., Yngveus, C.A. and Rosenlund, D. (2015) 'Historical consciousness and historical thinking reflected in large-scale assessment in Sweden'. In K. Ercikan and P. Seixas (eds), New Directions in Assessing Historical Thinking. New York: Routledge, 171-82.

Friedrich, D. (2014) Democratic Education as a Curricular Problem: Historical consciousness and the moralizing limits of the present. New York: Routledge.

Gosselin, V. and Livingstone, P. (eds) (2016) Museums and the Past: Constructing historical consciousness. Vancouver: UBC Press.

Grever, M. and Adriaansen, R.J. (2019) 'Historical consciousness: The enigma of different paradigms'. Journal of Curriculum Studies, 51 (6), 814-30. https://doi.org/10.1080/00220272.2019. 1652937.

Grever, M., Haydn, T. and Ribbens, K. (2008) 'Identity and school history: The perspective of young people from the Netherlands and England'. British Journal of Educational Studies, 56 (1), $76-94$. https://doi.org/10.1111/j.1467-8527.2008.00396.x.

Grever, M., Pelzer, B. and Haydn, T. (2011) 'High school students' views on history'. Journal of Curriculum Studies, 43 (2), 207-29. https://doi.org/10.1080/00220272.2010.542832.

Haydn, T. and Harris, R. (2010) 'Pupil perspectives on the purposes and benefits of studying history in high school: A view from the UK'. Journal of Curriculum Studies, 42 (2), 241-61. https://doi.org/10.1080/00220270903403189.

Henderson, A.G. and Levstik, L.S. (2016) 'Reading objects: Children interpreting material culture'. Advances in Archaeological Practice, 4 (4), 503-16. https://doi.org/10.7183/2326-3768.4.4.503.

Jarvis, P. (2018) 'A comprehensive understanding of human learning'. In K. Illeris (ed.), Contemporary Theories of Learning: Learning theorists ... In their own words. 2nd ed. New York: Routledge, 15-28.

Jones, S. (2016) 'Unlocking essences and exploring networks: Experiencing authenticity in heritage education settings'. In C. Van Boxtel, M. Grever and S. Klein (eds), Sensitive Pasts? Questioning heritage in education. New York: Berghahn Books, 130-52.

Karlsson, K.G. (2011) 'Processing time - on the manifestations and activations of historical consciousness'. In H. Bjerg, C. Lentz and E. Thorstensen (eds), Historicizing the Uses of the Past: Scandinavian perspectives on history culture, historical consciousness and didactics of history related to World War II. Bielfeld: Transcript, 129-43.

Kelly, A., Lesh, R.A. and Baek, J.Y. (eds) (2008) Handbook of Design Research Methods in Education: Innovations in science, technology, engineering, and mathematics learning and teaching. New York: Routledge.

Knowles, J.G. and Cole, A.L. (2008) Handbook of the Arts in Qualitative Research: Perspectives, methodologies, examples, and issues. Thousand Oaks, CA: Sage.

Kölbl, C. and Straub, J. (2011) 'Historical consciousness in youth: Theoretical and exemplary empirical analyses'. Forum: Qualitative Social Research/Sozialforschung, 2 (3). https://doi.org/10.17169/fqs-2.3.904.

Körber, A. (2015) Historical Consciousness, Historical Competencies - and Beyond? Some conceptual development within German history didactics. 56 S, 1-56. https://doi.org/10.25656/01:10811.

Körber, A. and Meyer-Hamme, J. (2015) 'Historical thinking, competencies, and their measurement'. In K. Ercikan and P. Seixas (eds), New Direction in Assessing Historical Thinking. New York: Routledge, 165-82.

Köster, M., Thunemann, H. and Zulsdorf-Kersting, M. (eds) (2014) Researching History Education: International perspectives and disciplinary traditions. Schwalbach: Wochenschau.

Laville, C. (2004) 'Historical consciousness and historical education: What to expect from the first for the second'. In P. Seixas (ed), Theorizing Historical Consciousness. Toronto: University of Toronto Press, 165-82.

Lee, P. (2004) '"Walking backwards into tomorrow": Historical consciousness and understanding history'. International Journal of Historical Learning, Teaching and Research, 4 (1), 69-114.

Lee, P. (2011) 'Historical thinking and transformative history'. In L. Periklous and D. Shemilt (eds), The Future of the Past: Why history education matters. Nicosia: Association for Historical Dialogue and Research, 129-54. 
Lee, P. and Howson, J. (2009) 'Two out of five did not know that Henry VIII had six wives: Historical literacy and historical consciousness'. In L. Symcox and A. Wilschut (eds), National History Standards: The problem of the canon and the future of teaching history. Charlotte, NC: Information Age Publishers, 211-64.

Lee, P. and Shemilt, D. (2004) '"I just wish we could go back in the past and find out what really happened": Progression in understanding about historical accounts'. Teaching History, 117, 25-31. Accessed 14 July 2021. www.history.org.uk/secondary/categories/8/resource/103.

Lee, P. and Shemilt, D. (2011) 'The concept that dares not speak its name: Should empathy come out of the closet?'. Teaching History, 143, 39-49.

Levisohn, J.A. (2010) 'Negotiating historical narratives: An epistemology of history for history education'. Journal of Philosophy of Education, 44 (1), 1-21. https://doi.org/10.1111/j.14679752.2010.00737.x.

Levstik, L.S. and Barton, K.C. (2008) Researching History Education: Theory, method, and context. New York: Routledge.

Levy, S. (2017) 'How students navigate the construction of heritage narratives'. Theory and Research in Social Education, 45 (2), 157-88. https://doi.org/10.1080/00933104.2016.1240636.

Maxwell, J.A. and Miller, B.A. (2008) 'Categorizing and connecting strategies in qualitative data analysis'. In P. Leavy and S. Hesse-Biber (eds), Handbook of Emergent Methods. New York: Guilford Press, 461-77.

McKenney, S.E. and Reeves, T.C. (2019) Conducting Educational Design Research. 2nd ed. New York: Routledge.

Miles, M.B., Huberman, A.M. and Saldana, J. (2014) Qualitative Data Analysis: A methods sourcebook. 3rd ed. Thousand Oaks, CA: Sage.

Nordgren, K. (2016) 'How to do things with history: Use of history as a link between historical consciousness and historical culture'. Theory and Research in Social Education, 44 (4), 479-504. https://doi.org/10.1080/00933104.2016.1211046.

Nordgren, K. (2019) 'Boundaries of historical consciousness: A Western cultural achievement or an anthropological universal?'. Journal of Curriculum Studies, 51 (6), 779-97. https://doi.org/10.1080/ 00220272.2019 .1652938$.

Nordgren, K. and Johansson, M. (2015) 'Intercultural historical learning: A conceptual framework'. Journal of Curriculum Studies, 47 (1), 1-25. https://doi.org/10.1080/00220272.2014.956795.

Osborne, K. (2006) '"To the past": Why we need to teach and study history'. In R.W. Sandwell (ed.), To the Past: History education, public memory, and citizenship in Canada. Toronto: University of Toronto Press, 103-31.

Patrick, L.D. (2016) 'Found poetry: Creating space for imaginative arts-based literacy research writing'. Literacy Research: Theory, method, and practice, 65 (1), 384-403. https://doi.org/10.1177/2381336916661530.

Peck, C. (2018) 'National, ethnic, and indigenous identities and perspectives in history education'. In S.A. Metzger and L.M. Harris (eds), The Wiley International Handbook of History Teaching and Learning. Hoboken, NJ: Wiley-Blackwell, 311-34.

Plomp, T. and Nieveen, N.M. (eds) (2013) Educational Design Research - Part A: An introduction. Enschede: Netherlands Institute for Curriculum Development.

Popa, N. (under review) 'Cultivating historical consciousness in history classrooms: A meaningcentred and practice-oriented instructional model'.

Popa, N. (in press) 'Operationalizing historical consciousness: A review and synthesis of the literature on meaning making in historical learning'.

Retz, T. (2015) 'A moderate hermeneutical approach to empathy in history education'. Educational Philosophy and Theory, 47 (3), 214-26. https://doi.org/10.1080/00131857.2013.838661.

Rogers, R. (2008) 'Raising the bar: Developing meaningful historical consciousness at Key Stage 3'. Teaching History, 133, 24-31. Accessed 26 July 2021. www.history.org.uk/secondary/categories/8/ resource/1982.

Rüsen, J. (2004) 'Historical consciousness: Narrative, structure, moral function, and ontogenetic development'. In P. Seixas (ed.), Theorizing Historical Consciousness. Toronto: University of Toronto Press, 63-85.

Rüsen, J. (2005) History: Narration, interpretation, orientation. New York: Berghahn Books.

Rüsen, J. (2012) 'Forming historical consciousness: Towards a humanistic history didactics'. Antitesis, 5 (10), 519-36. Accessed 14 July 2021. https://dialnet.unirioja.es/servlet/ articulo?codigo $=5026701$.

Sandoval, W.A. (2014) 'Conjecture mapping: An approach to systematic educational design research'. Journal of the Learning Sciences, 23 (1), 18-36. https://doi.org/10.1080/10508406.2 013.778204 . 
Saye, J.W. (2017) 'Disciplined inquiry in social studies classrooms'. In M. McGlinn Manfra and C. Mason Bolick (eds), The Wiley Handbook of Social Studies Research. Hillsdale, NJ: John Wiley and Sons, 336-59.

Seixas, P. (2012) 'Progress, presence and historical consciousness: Confronting past, present and future in postmodern time'. Paedagogica Historica: International Journal of the History of Education, 48 (6), 859-72. https://doi.org/10.1080/00309230.2012.709524.

Seixas, P. (2015) 'A model of historical thinking'. Educational Philosophy and Theory, 49 (6), 593-605. https://doi.org/10.1080/00131857.2015.1101363.

Seixas, P. (2017) 'Historical consciousness and historical thinking'. In M. Carretero, S. Berger and M. Grever (eds), Palgrave Handbook of Research in Historical Culture and Education. London: Palgrave Macmillan, 59-72.

Seixas, P. and Morton, T. (2013) The Big Six Historical Thinking Concepts. Toronto: Nelson Education.

Stearns, P.N., Seixas, P. and Wineburg, S. (eds) (2000) Knowing, Teaching and Learning History: National and international perspectives. New York: New York University Press.

Sullivan, A. (2009) 'On poetic occasion in inquiry: Concreteness, voice, ambiguity, tension and associative logic'. In M. Prendergast (ed.), Poetic Inquiry: Vibrant voices in the social sciences. Rotterdam: Sense Publishers, 111-26.

Thorp, R. and Persson, A. (2020) 'On historical thinking and the history educational challenge'. Educational Philosophy and Theory, 52 (8), 891-901. https://doi.org/10.1080/00131857.2020 1712550.

Traille, K. (2007) "“You should be proud about your history. They made me feel ashamed": Teaching history hurts'. Teaching History, 127, 31-7.

VanSledright, B.A. (1998) 'On the importance of historical positionality to thinking about and teaching history'. International Journal of Social Education, 12 (2), 1-18.

VanSledright, B. (2011) The Challenge of Rethinking History Education: On practices, theories, and policy. New York: Routledge.

Van Straaten, D., Wilschut, A. and Oostdam, R. (2015) 'Making history relevant to students by connecting past, present, and future: A framework for research'. Journal of Curriculum Studies, 48 (4), 479-502. https://doi.org/10.1080/00220272.2015.1089938.

Van Straaten, D., Wilschut, A. and Oostdam, R. (2018) 'Exploring pedagogical approaches for connecting the past, the present and the future in history teaching'. Historical Encounters, 5 (1), 46-67. Accessed 14 July 2021. https://www.researchgate.net/publication/326391670_Exploring_ pedagogical_approaches_for_connecting_the_past_the_present_and_the_future_in_history_ teaching.

Virta, A. (2016) 'Whose history should be dealt with in a pluricultural context - Immigrant adolescents' approach'. Intercultural Education, 27 (4), 377-87. https://doi.org/10.1080/14675986. 2016.1216950.

Von Borries, B. (2011) 'Historical consciousness and historical learning: Some results of my own empirical research'. In L. Perikleous and D. Shemilt (eds), The Future of the Past: Why history education matters. Nicosia: The Association for Historical Dialogue and Research, 283-321.

Waldis, M., Hodel, J., Thünemann, H., Zülsdorf-Kersting, M. and Ziegler, B. (2015) 'Materialbased and open-ended writing tasks for assessing narrative competence among students'. In K. Ercikan and P. Seixas (eds), New Directions in Assessing Historical Thinking. New York: Routledge, 117-31.

Wertsch, J.V. (2004) 'Specific narratives and schematic narrative templates'. In P. Seixas (ed.), Theorizing Historical Consciousness. Toronto: Toronto University Press, 117-31.

Wilschut, A. (2012) Images of Time: The role of a historical consciousness of time in learning history. Charlotte, NC: Information Age Publishing.

Wineburg, S., Mosborg, S., Porat, D. and Duncan, A. (2007) 'Common belief and the cultural curriculum: An intergenerational study of historical consciousness'. American Educational Research Journal, 44 (1), 40-76. https://doi.org/10.3102/0002831206298677.

Zanazanian, P. and Nordgren, K. (eds) (2019) 'Revisiting historical consciousness as a theoretical construct and exploring its broad understanding for contemporary education and educational research'. Journal of Curriculum Studies, 51 (6), 850-68. https://doi.org/10.1080/00220272.2019. 1652940.

Zanazanian, P. and Popa, N. (2018) 'Using a narrative tool to help Quebec English-speaking students produce personal histories of belonging'. LEARNing Landscapes, 11 (2), 365-79. https://doi.org/10.36510/learnland.v11i2.969. 